\title{
Developing Responsibility for Learning in Higher Education in Tanzania: Experiences from Undergraduate Programmes
}

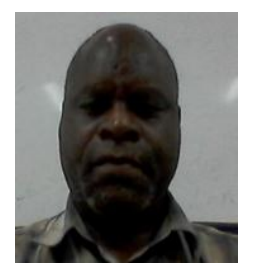

(\&) Corresponding Author)

\author{
(i) Bryson D. Kinyaduka \\ (D) Perpetua J. Kalimasi ${ }^{2}$ \\ Anja Heikkinen ${ }^{3}$
}

American Journal of Education and Learning

Vol. 4, No. 1, 62-69, 2019

e-ISSN:2518-6647

\author{
PhD Student, Mzumbe University, Tanzania \\ Email:bdkinyaduka@mzumbe.ac.tz \\ PhD Mzumbe University, Tanzania. \\ Email:pjkalimasi@mzumbe.ac.tz \\ ${ }^{3}$ Prof. Dr., Tampere University, Finland. \\ Email: anja.heikkinen@tunifi
}

In recent years, the requirement for students to shoulder responsibility for learning has been conceived as one of important attributes of a student or a graduate. This attribute is assumed to be developed through the application of competence-Base Model (CBM) in higher education as opposed to the application of the Traditional Model (lecture to seminar model) practiced in higher education for centuries. Given the importance of shouldering the responsibility for learning among students, particularly, in developing lifelong learning attitude among students, it was thus vital to study to understand whether or not the instructional models designated to operate or the implemented instructional models developed the important feature among undergraduate students. This study adopted a longitudinal study design. This study had a sample size of 183 respondents in phase I and a sample size of 70 respondents in phase II. Further, the study used questionnaire to collected data in two consecutive semesters to year one undergraduates. The Elusive Competence-Based Model (ECBM) and the Elevated Traditional Model (ETM) were instruction models in operation at the time of this study. The ECBM resulted in gradual deterioration of students' responsibility for learning whereas the ETM resulted in gradual development of students' responsibility for learning toward a positive direction. The study concludes that the use of seminars in an effective way contributes in promoting responsibility for learning among undergraduate students.

Keywords: Responsibility for learning, higher education, Undergraduate students, Instructional models, Implemented instructional models, Competence-based model, Traditional model, Elusive competence-based model, Elevated competence-based model.

DOI: $10.20448 / 804.4 .1 .62 .69$

Citation | Bryson D. Kinyaduka; Perpetua J. Kalimasi; Anja Heikkinen (2019). Developing Responsibility for Learning in Higher Education in Tanzania: Experiences from Undergraduate Programmes. American Journal of Education and Learning, 4(1): 62-69.

Copyright: This work is licensed under a Creative Commons Attribution 3.0 License

Funding: This study received no specific financial support.

Competing Interests: The authors declare that they have no competing interests.

History: Received: 15 January 2019/ Revised: 20 February 2019/ Accepted: 22 March 2019/ Published: 30 May 2019

Publisher: Online Science Publishing 


\section{INTRODUCTION}

In recent years, Tanzania higher education system has adopted the competence-Based model (CBM) for teaching and learning. This instructional model is believed to develop ability to shoulder responsibility for learning among students; in our view, this is one of the most important attitudes of lifelong learning. The CBM as an instructional model has a number of dimesions for lifelong learning it develops one of which is ability to shoulder responsibility for learning among students. The instructional model is believed to develop this dimension of lifelong learning through allowing students to plan for their own learning, think about their own learning, learning what one wants to learn from whoever, assess one's learning, demonstrate ability to use prior learning and ability make sense of what one learns ( Kerby, Knapper, Lamon and Egnatoff, 2010). The combination of these attributes results in ability of a student to shoulder responsibility for learning. Indeed, the development of responsibility for learning requires more research on how to develop this dimension of lifelong learning in a classroom setting (Carpenter and Pease, 2013). Helping students develop responsibility for learning, it makes students succeed in school and beyond (Carpenter and Pease, 2013). This is to say, creating successful graduates beyond the classroom walls, it should be the primary object of any formal education endeavour today.

Given the importance of student shouldering the responsibility for learning, scholars (Ahmad and Razeq, 2014) studied to understand perceptions of higher education students on whether or not they felt that they were autonomous learners. Experience influenced the way student perceived themselves as autonomous learners; moreover, students felt that had ability to learn independently if their teachers allowed them to learn in that way. These scholars proposed more similar studies to be conducted in other settings. Another group of scholars (Osman et al., 2015) sought to understand what lecturers and students thought about the new approach, students felt that could become motivated and independent learners if lecturers used peer teaching and learning. However, the study points out that lecturers lacked skills to teach developing independent learners; thus training for lecturers was recommended. According to Virtanen et al. (2017) a very high degree of self-regulation is a function of active learning methods. In other words, to make students independent learners the use of active methods of learning is the best practice. Again, Santikarn and Wichadee (2018) studied about the effect of flipped classroom in an English language course. Students reported developing responsibility for learning independently from flipped classrooms, and that their perceptions on ability to learn independently were higher than those before teaching through flipped classrooms.

In addition, the learning environment in the CBM has features such as students sitting in circles, noisy classes, students talking more than their teachers, use of authentic assessment and formative assessment. Moreover, teachings methods include group works, individual assignments, collaborative learning, work based learning, project-based learning and any other form of active learning a teacher devises (see (Sullivan and McIntonsh, 1996; Bierne et al., 2017)). In other words, teaching and learning process in the CBM is mainly student-centred. Creating learning environment like this, cultivates responsibility for learning among students. In that regard, the CBM is assumed to develop responsibility for learning.

In contrast, the traditional model (TM) from the methods used in this model does not develop responsibility for learning among students. The methods that are common in the traditional model include but may not be limited to: lecture method, choral repetition, imitation, memorization, and demonstration (Westbrook et al., 2013). These methods make students passive receivers of information, and the likelihood is that they do not promote ability to think in a divergent way. As such, students are not likely to excel in life beyond schools.

Moreover, the learning environment under the traditional model (TM) which include students sitting in rows, passive classes, teachers having more powers in classes, teachers using examination as the best form of assessment. 
Indeed, in principle, teachers use teacher-centred methods in the instructional model. These methods are assumed not to promote responsibility for learning among students (Gautam et al., 2018). Though this is the assumption, it is not clear whether or not the implemented instructional models in higher education institutions develop responsibility for learning among students in the context of Tanzania higher education institutions.

Indeed, the concept of student responsibility for learning is directly connected to understanding of learners as people who are not tabula rasa (Todorovski et al., 2015). In this sense, students do not go to school to be fed information, but rather to find information and make sense out of the information they find to make use of it in their life. As such, professor's job is to facilitate students learn how to learn (Klopfenstein, 2003; Dano-Himosolango and Vedua-Dinagsao, 2014; Todorovski et al., 2015). Learning how to learn is the most important skill because it prepares the graduates to be lifelong learners; consequently, they can face whatsoever changes happening in the really life situations (Scharle and Szabo, 2000; Carpenter and Pease, 2013). From this importance of students shouldering the responsibility for learning to control their future life, professors have to create learning environment which can cultivate independent learning among students in order to produce graduates who can learn autonomously through life after graduation (McCabe and O'Connor, 2014). In this regard, one study (Allan, 2006) sought to understand whether or not students felt that they were responsible learners. The learners felt that they were responsible students; this contradicted what most of literature established that students are not responsible learners. In the view of the literature, the question is, are learning environments and learning strategies created and employed, respectively, in Tanzania higher education institutions equip undergraduate students with tools to be responsible learners?

\section{METHODS}

This study adopted a longitudinal research design to understand whether or not responsibility for learning orientation developed among year one undergraduates when they progressed with their studies through two semesters. The study included two higher education institutions assumed to have different instructional models, namely Competence-Based Model (CBM) and the Traditional Model (TM). The CBM requires students to shoulder the responsibility for learning among other requirements while the TM requires professors to play a more active role at some point in the teaching and learning process, but they play a bit passive role at some point in student learning process. The difference of the two institutions made the researcher include the two higher education institutions in the study. The purpose was to compare year one undergraduates from selected programmes from the two different learning environments whether or not they had same level of development in terms of responsibility for learning. The two institutions were selected purposively because institution M2 offered a degree in education under CBM environment and institution D offered a bachelor degree under TM environment. However, since the researchers wwere interested to know the extent to which the two instructional models were implemented, the two institutions, M2 and D had Elusive Competence-Based Model $^{1}$ (ECBM) and the Elevated Traditional Model $^{2}$ (ETM), respectively. In the view of this, the study compares the development of responsibility for learning from the two institutions based on the two generated instructional models.

\footnotetext{
${ }^{1}$ Instructional model characterised by professors offering lectures followed by group and individual assignments without seminar sessions (presentations) in a programme

${ }^{2}$ Instructional model characterised by professors offering lectures followed by seminar sessions for some of courses in a programme. It an instructional model with diluted seminar sessions
} 
In this study, the researchers used 'blank cell technique' to indentify respondents who filled in the questionnaire without reading thoroughly. In this technique, the researchers included blank cells i.e. cells without statements, and then the researchers required the respondents to read the statements before ticking or filling in. In this situation, any questionnaire with blank cells filled in was assumed to be completed without reading, and therefore, it was not analysed. The researchers also used 'the odd out technique'. In this technique the respondents were required to star any statement they felt that they did not understand. In this way, the researchers would identify likert items which were probably not understood to respondents so that during analysis they would be removed from the analysis; however, there was no such a case in both phases.

In relation to sample size, the study used total sampling technique. This technique was preferred because in longitudinal studies for some reason the number of participants usually go down; therefore, including all expected respondents was the best option in this study. Table 1 shows expected and reached respondents by phases, programmes and institutions.

Table-1. Expected and reached respondents by phases, programmes and institutions

\begin{tabular}{|c|c|c|c|c|c|c|}
\hline \multirow[t]{2}{*}{ Phases } & \multirow[t]{2}{*}{$\begin{array}{c}\text { Respondent } \\
\text { category }\end{array}$} & $\begin{array}{l}\text { Programme\& } \\
\text { institutions }\end{array}$ & \multirow[t]{2}{*}{$\begin{array}{c}\text { Expected } \\
\text { respondents }\end{array}$} & \multirow[t]{2}{*}{$\begin{array}{c}\text { Reached } \\
\text { respondents }\end{array}$} & \multirow[t]{2}{*}{ Percent reached } & \multirow[t]{2}{*}{ Remarks } \\
\hline & & Institution $\mathrm{M} 2$ & & & & \\
\hline I & Students & B Ed & 100 & 80 & 79 & Suspicious \\
\hline II & Students & B Ed & 100 & 23 & 23 & suspicious \\
\hline & & Institution D & & & & \\
\hline I & students & BA Ed & 300 & 103 & 33.33 & Suspicious \\
\hline II & students & BA Ed & 103 & 47 & 45.6 & Suspicious \\
\hline
\end{tabular}

Table 1 shows that in institution $\mathrm{M} 2$ in phase I of data collection and analysis 100 respondents were expected to participate in the study; however, 80 respondents were reached amounting to $79 \%$ of expected responses. In the same institution in phase II, one hundred respondents were expected to be reached; however, twenty three were reached which amounts to $23 \%$ of expected responses. The number of respondents went down in phase two because most of respondents were not sincere in filing in the questionnaire in phase II.

Furthermore, the table shows that in institution D three hundred respondents were expected to be reached; however, 103 were reached in phase I of data collection. In phase II, 103 respondents were expected to reached in the study; however, 47 amounting to $45.6 \%$ were reached the rest filled in the questionnaire without sincerity and some of them did not show up to fill in the questionnaire. From the table, we see that a sample size of 400 respondents was expected. However, a sample of 183 respondents was reached in phase I and a sample of 70 respondents was reached in phase II. The remaining part of respondents was removed during analysis for the earlier said reasons.

This study used questionnaire to collect data from respondents. The data were collected from first year undergraduates from the two institutions. The questionnaire contents were on: preference for others to plan for one’s learning; reflection about one’s learning; self-directedness; self-assessment; relating new learning to old one; and responsibility to make sense. The questionnaire was adapted from scholars (Kirby et al., 2010; Hursen, 2016) who developed likert items for measuring lifelong learning attitude. From these contents the study measured ability of first year undergraduates to take responsibility for learning which was assumed to be developed in a twosemester period. Moreover, the study used total sampling techniques. the sampling technique was used because it was assumed that the number of respondents would decrease as the respondents filled in the questionnaires in the following phases of data collection. Indeed, the programmes included in this study were based on purposive 
sampling, the researcher selected programmes that the researchers were conversant with courses that were taught in programmes. This was the case because the researcher data from questionnaire were preceded by collection of data through class observations. Observation was done to determine the learning environment and teaching experiences in which students were exposed. With regard to data analysis, the study used Yehs Index of perception (YIP) in order to determine the development of responsibility for learning in two-semester duration in the two higher education institutions. The interpretation of the YIP was based on the following decision rules: below 0.20 means very low; 0.20-0.39 means low; 0.40-0.59 means medium; 0.60-0.79 means high and 0.80 and above means very high.

\section{RESULTS}

In institution $\mathrm{M} 2$, the institution which used the ECBM the results show that the overall average of the YIP respondent scores was high in phase I, at the beginning of phase I, and it appeared to gradually develop toward a negative direction in phase II, at the end of semester two of the training. Table 2 shows YIP scores for phase I and II of data collection by attitudes and their average scores on responsibility for learning among undergraduate respondents in institution $\mathrm{M} 2$.

Table-2. Results for responsibility for learning for phase I and II: institution M2.

\begin{tabular}{|c|c|c|c|c|c|c|c|c|}
\hline \multirow{2}{*}{$\begin{array}{c}\text { Dimensions and Likert } \\
\text { items } \\
\begin{array}{c}\text { Responsibility for } \\
\text { learning }\end{array}\end{array}$} & \multicolumn{3}{|c|}{$\begin{array}{c}\text { Likert scale response in \% } \\
\text { phase I }\end{array}$} & \multicolumn{3}{|c|}{$\begin{array}{c}\text { Likert scale response in \% } \\
\text { phase II }\end{array}$} & \multirow[t]{2}{*}{$\begin{array}{l}\text { YIP- } \\
\text { I }\end{array}$} & \multirow[t]{2}{*}{$\begin{array}{c}\text { YIP- } \\
\text { II }\end{array}$} \\
\hline & Disagree & Undecided & Agree & Disagree & Undecided & Agree & & \\
\hline $\begin{array}{c}\text { Prefer others plan for my } \\
\text { learning }\end{array}$ & 3.75 & 15.0 & 81.25 & 4.5 & 13.6 & 81.8 & 0.96 & 0.77 \\
\hline $\begin{array}{l}\text { I rarely think about my } \\
\text { learning }\end{array}$ & 11.25 & 15.0 & 73.5 & 9.1 & 9.1 & 81.8 & 0.62 & 0.72 \\
\hline $\begin{array}{c}\text { I feel self-directed } \\
\text { learner }\end{array}$ & 15.00 & 18.75 & 66.25 & 18.2 & 22.7 & 59.1 & 0.51 & 0.40 \\
\hline $\begin{array}{c}\text { Others evaluate my } \\
\text { learning }\end{array}$ & 15.0 & 12.5 & 72.5 & 4.5 & 36.4 & 59.1 & 0.57 & 0.54 \\
\hline $\begin{array}{l}\text { Relate new to prior } \\
\text { learning }\end{array}$ & 5.0 & 3.75 & 91.25 & 4.5 & 9.1 & 86.4 & 0.86 & 0.81 \\
\hline $\begin{array}{c}\text { Responsible in making } \\
\text { sense }\end{array}$ & 5.0 & 2.5 & 92.5 & 0.0 & 4.5 & 95.5 & 0.87 & 0.95 \\
\hline \multicolumn{7}{|c|}{ Average for YIP } & 0.73 & 0.70 \\
\hline
\end{tabular}

In institution D, the institution which used the ETM overall results show that respondents had high ability in terms of taking responsibility for learning in phase I, at the beginning of semester one, and the ability appeared to develop towards a positive direction in phase II, at the end of semester two of their training. Table 3 shows the YIP average score in phase I and II by attitudes and their average scores for responsibility for learning among undergraduates for institution D. 
Table-3. Results for responsibility for learning in phase I and II: institution D.

\begin{tabular}{|c|c|c|c|c|c|c|c|c|}
\hline $\begin{array}{l}\text { Dimensions and } \\
\text { Likert items }\end{array}$ & \multicolumn{3}{|c|}{$\begin{array}{c}\text { Likert scale responses in \% } \\
\text { phase I }\end{array}$} & \multicolumn{3}{|c|}{$\begin{array}{c}\text { Likert scale response in \% } \\
\text { phase II }\end{array}$} & \multirow[t]{2}{*}{$\begin{array}{l}\text { YIP- } \\
\text { I }\end{array}$} & \multirow[t]{2}{*}{$\begin{array}{l}\text { YIP- } \\
\text { II }\end{array}$} \\
\hline $\begin{array}{l}\text { Responsibility for } \\
\text { learning }\end{array}$ & Disagree & Undecided & Agree & Disagree & Undecided & Agree & & \\
\hline $\begin{array}{l}\text { Others plan for my } \\
\text { learning }\end{array}$ & 1.9 & 8.8 & 89.3 & 4.3 & 4.3 & 91.4 & 0.87 & 0.87 \\
\hline $\begin{array}{l}\text { I rarely think about } \\
\text { my learning }\end{array}$ & 6.8 & 14.6 & 78.6 & 2.1 & 17.0 & 80.9 & 0.71 & 0.79 \\
\hline $\begin{array}{c}\text { I feel self-directed } \\
\text { learner }\end{array}$ & 10.7 & 25.2 & 64.1 & 8.5 & 23.4 & 68.1 & 0.53 & 0.59 \\
\hline $\begin{array}{l}\text { Others evaluate my } \\
\text { learning }\end{array}$ & 19.4 & 21.4 & 59.2 & 10.6 & 21.3 & 68.1 & 0.39 & 0.57 \\
\hline $\begin{array}{c}\text { Relate new to prior } \\
\text { learning }\end{array}$ & 2.9 & 2.9 & 94.2 & 2.1 & 8.5 & 89.4 & 0.91 & 0.87 \\
\hline $\begin{array}{c}\text { Responsible in making } \\
\text { sense }\end{array}$ & 0.0 & 6.8 & 93.2 & 2.1 & 4.3 & 93.6 & 0.93 & 0.91 \\
\hline \multicolumn{7}{|c|}{ Average for YIP } & 0.72 & 0.76 \\
\hline
\end{tabular}

\subsection{Cross-Case Analysis}

Looking into the two institutions, the institutions had almost the same level (high level) of development of responsibility for learning with only 0.01 differences at the time they joined the institutions (in phase I) with institution D YIP average score being sparingly lower than that of institution M2. On the contrary, in phase II, institution M2 had lower YIP average score when compared to that of institution D in the same phase although both institutions remained high.

\section{DISCUSSION}

The implemented instructional model in institution M2 is ECBM, the learning environment of which results in gradual development of ability to shoulder responsibility for learning among students toward a negative direction i.e. gradual deterioration. This implies that the absence of seminar sessions in the instructional model applied in institution $\mathrm{M} 2$ result in the development toward a negative direction of ability to take responsibility for learning among students. The findings agree with the view that the CBM results in the development of student ability to take responsibility for learning (Dano-Himosolango and Vedua-Dinagsao, 2014; Gautam et al., 2018). This further implies that the students are likely to keep deteriorating in ability to take responsibility for learning as they proceed with their studies through the undergraduate education cycle.

The implemented instructional model in institution D is ETM, the learning environment of which develops ability to shoulder responsibility for learning toward a positive direction. This implies that the presence of seminar sessions (presentations) in some courses in this instructional model contributes to the development of responsibility for learning among students.

The entrants in the undergraduate programmes in the two institutions have similar level of development of responsibility for learning when joining the programmes. This implies that students join undergraduate programmes when they have similar level (high) responsibility for learning. Furthermore, as the students progress with their studies, those under the ETM demonstrate some degree of development toward a positive direction while those under the ECBM demonstrate development towards a negative direction. This implies that the learning environment created under the ETM contribute to the development of responsibility for learning among students whereas the learning environment created under the ECBM does not promote the development of responsibility for 
learning among students. These findings are similar to those of Virtanen et al. (2017) who report that active methods used for student teachers result in very high self-regulation among student teachers.

\section{CONCLUSIONS}

The ETM appears to culminate in the development of ability to shaoulder responsibility for learning towards a positive direction whereas the ECBM seems to result in the development of ability to shoulder responsibility for learning toward a negative direction. Again, the development toward a positive direction of ability to shoulder responsibility for learning under the ETM is gradual, and the development toward a negative direction of the same happens in a gradual way. In the view of this understanding, the responsibility for learning develops better when students use seminar sessions effectively in all courses than when students do not have seminar sessions in all courses in a programme, but they have individual and group assignments.

\section{ACKNOWLEDGEMENTS}

The authors extend gratitude to respondents of this study for sparing the time to fill in the question which resulted in the development of this paper. Moreover, the authors are thankful to reviewers of the American Journal of Education and Learning for their comments on the manuscript which contributed in improving the quality of this article

\section{REFERENCES}

Ahmad, A. and A. Razeq, 2014. University EFL learners' perception of their autonomous learning responsibilities and abilities. RELL Journal, 45(3): 321-336.Available at: https://doi.org/10.1177/0033688214547035.

Allan, G.M., 2006. Responsibility for learning: Students' understandings and their self-reported learning attitudes and behaviours. Master's Thesis, Queensland University of Technology.

Bierne, J., J. Titko, E. Cerkovskis and A. Lasmane, 2017. Advance teaching medthods for students competences development.

Available

from

https://www.researchgate.net/publication/317169205_ADVANCED_TEACHING_METHODS_FOR_STUDENTS

\%27_COMPETENCIES_DEVELOPMENT?enrichId=rgreq-c5a7d3d6999e997b77473f4a92 1031d9-

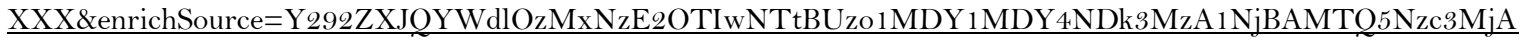

1MTEyMQ\%3D\%3D\&el=1_x_2\&_esc=publicationCoverPdf [Accessed 12 April, 2019].

Carpenter, J.P. and J.S. Pease, 2013. Preparing students to take responsibility for learning: The role of non-curricular learning strategies. Journal of Curriculum and Instruction, 7(2): 38-55.Available at: https://doi.org/10.3776/joci.2013.v7n2p38-55.

Dano-Himosolango, M.A. and A. Vedua-Dinagsao, 2014. The impact of learner-centred teaching on students' learning skills and strategies. International Journal for Cross-disciplinary Subjects in Education, 5(4): 1813-1817.

Gautam, S., S. Jangam and K.C. Loh, 2018. Developing responsible learners. Chemical Engineering Education, 52(1): 23-30.

Hursen, C., 2016. A scale of lifelong learning attitudes of teachers: The development of LLLAS. Cypriot Journal of Educational Sciences, 11(1): 21-37.Available at: https://doi.org/10.18844/cjes.v1111.430.

Kirby, J.R., C. Knapper, P. Lamon and W.J. Egnatoff, 2010. Development of a scale to measure lifelong learning. International Journal of Lifelong Education, 29(3): 291-302.Available at: https://doi.org/10.1080/02601371003700584.

Klopfenstein, B.J., 2003. Empowering learners: Strategies for fostering self-directed learning and implications for online learning. Master's Thesis. University of Alberta. 
McCabe, A. and U. O'Connor, 2014. Student-centred learning: 'Letting go' the role and responsibility of the lecturers. Dundalk: Insitute of Technology.

Osman, S.Z.M., R. Jamaludin and M. Iranmanesh, 2015. Student centered learning at USM: What lecturer and students think of this new approach? Journal of Education and Practice, 6(19): 264-277.

Santikarn, B. and S. Wichadee, 2018. Flipping the classroom for English language learners: A study of learning performance and perceptions. International Journal of Emerging Technologies in Learning (iJET), 13(09): 123-135.Available at: https://doi.org/10.3991/ijet.v 13io9.7792.

Scharle, A. and A. Szabo, 2000. Learner autonomy: A guide to developing learner responsibility. Cambridge: Cambridge University City Press.

Sullivan, R. and N. McIntonsh, 1996. The competency-based approach to training. Competence Based Training, 5(2): 95-98.

Todorovski, B., E. Nordal and T. Isoski, 2015. Overview on student-centred learning in higher education in Europe: Research study. Brussels: European Students Union.

Virtanen, P., H.M. Niemi and A. Nevgi, 2017. Active learning and self-regulation enhance student teachers' professional competences. Australian Journal of Teacher Education, 42(12): 1-20.

Westbrook, J., N. Durrani, R. Brown, D. Orr, J. Pryor, J. Boddy and F. Salvi, 2013. Pedagogy, curriculum, teaching practices and teacher education in developing countries. Education rigorous literature review. London, UK: Department for International Development (DFID). pp: iv + 144 .

Online Science Publishing is not responsible or answerable for any loss, damage or liability, etc. caused in relation to/arising out of the use of the content. Any queries should be directed to the corresponding author of the article. 